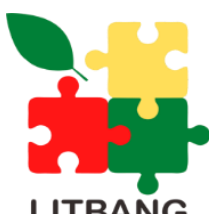

LITBANG

Edusaintech

\section{Jurnal Litbang Edusaintech (JLE)}

http://journal.pwmjateng.com/index.php/jle

\title{
Alternatif Remediasi Limbah Cair Industri Keripik Singkong (Manihot utilissima) Menggunakan Tanaman Air dan Tawas
}

\author{
Andang Syaifudin ${ }^{1}$ Ziya Rosyidatin Nazila ${ }^{1}$ \\ ${ }^{1}$ Department of Biology, Faculty of Science and Technology UIN Walisongo, Semarang 50185, Indonesia
}

* Correspondence: E-mail: andang.syaifudin@walisongo.ac.id

\begin{abstract}
A B S T R A C T S
In the processing of chips using cassava (Manihot utilissima), it will produce waste in the form of solid and liquid waste. The liquid waste of processing cassava chips contains organic compounds that are easily decomposed and cause unpleasant odors. If the liquid waste is discharged directly into the environment, it will cause pollution and damage the environment. One of the steps that can be used to overcome this problem is phytoremediation. The purpose of this study was to determine the best treatment in the processing of cassava chips industrial wastewater so that the liquid waste is safe to dispose of into the environment. In this study, using two types of aquatic plants, namely water hyacinth (Eichhornia crassipes) and kiambang (Pistia stratiotes) and using alum to remediate liquid waste. This research was conducted experimentally using a jar with a diameter of 15 $\mathrm{cm}$ and a height of $25 \mathrm{~cm}$ with 3 repetitions of each treatment. The data obtained were analyzed descriptively to determine the best treatment that can be used for remediation of cassava chips industry wastewater. The results showed that the use of water hyacinth plants (Eichhornia crassipes) could improve the quality of wastewater so that it is safe to dispose of into the environment.
\end{abstract}

\begin{tabular}{l} 
A R T I C L E I N FO \\
\hline Article History: \\
Received 10 Oct 2020 \\
Revised 10 Nov 2020 \\
Accepted 10 Dec 2020 \\
Available online 15 Dec 2020 \\
Keyword: \\
kiambang, \\
liquid waste, \\
remediation, \\
water byacinth
\end{tabular}

Keyword:

kiambang,

limbah cair,

remediasi,

tawas 


\section{PENDAHULUAN}

Indonesia memiliki banyak industri yang menjadi lahan pekerjaan bagi sebagian masyarakat baik industri berskala besar maupun industri berskala kecil atau industri rumahan. Salah satu industri rumahan yang banyak berkembang di Indonesia adalah industri keripik singkong atau ubi kayu. Berkembangnya industri ini didukung dengan ketersediaan bahan baku yang mudah didapat. Singkong dapat ditanam di lahan dengan berbagai macam jenis tanah dan tidak membutuhkan perawatan yang khusus. Kabupaten Jepara merupakan salah satu wilayah yang memiliki industri keripik singkong di dalamnya. Luas lahan ubi kayu atau singkong yang berada di Jepara yaitu 9,937 ha dan produktivitas $314,42 \mathrm{ku} /$ ha serta jumlah produksi sebanyak 312,4239 ton (Badan Pusat Statistik Provinsi Jawa Tengah, 2015).

Selain menghasilkan produk utama berupa keripik singkong, industri keripik singkong juga menghasilkan limbah atau sisa olahan dari proses pengolahan baik berupa limbah padat, cair, maupun gas. Ketiga jenis limbah tersebut sering kali menimbulkan dampak negatif. Salah satu limbah yang paling sering menimbulkan dampak negatif terhadap lingkungan yaitu limbah cair. Limbah cair hasil produksi keripik singkong ini sebelum dibuang ke lingkungan pada umumnya tidak melalui pengolahan terlebih dahulu. Sehingga akan menimbulkan pencemaran di sekitar lingkungan produksi dan tempat pembuangan limbah.(Felani hamzah)

Pembuangan limbah dari industri akan mempengaruhi sumber daya air, kesuburan tanah, organisme akuatik dan ekosistem (Priya \& Selvan, 2017). Limbah tersebut tidak akan menimbulkan pencemaran jika dilakukan pengolahan terlebih dahulu sebelum dibuang ke lingkungan. Proses pengolahan limbah memiliki tujuan untuk mengurangi bahan tercemar dan beracun yang terkandung di dalam limbah tersebut. Penelitian mengenai pengolahan limbah secara sederhana dan ekonomis masih dinilai perlu dilakukan karena pada praktik yang terjadi di lapangan masih banyak yang membuang limbah tanpa melalui proses pengolahan terlebih dahulu sehingga banyak terjadi pencemaran akibat buangan limbah industri. Meskipun pemerintah telah memberikan peraturan mengenai tata cara

pembuangan limbah ke lingkungan (Felani \& Hamzah, 2007). Akan tetapi masyarakat yang memiliki industri menganggap limbah cair dari pengolahan keripik singkong tidak menyebabkan pencemaran lingkungan.

Proses pengolahan limbah cair dapat dilakukan dengan berbagai cara diantaranya secara fisika, kimia dan biologi. Pengolahan limbah secara biologi salah satunya dapat menggunakan tanaman yang secara alami memiliki daya serap dan dapat mengakumulasi logam beracun serta zat organik dalam jaringan tanaman (Felani \& Hamzah, 2007). Teknik pengolahan menggunakan tanaman disebut dengan teknik fitoremediasi. Fitoremediasi adalah salah satu teknologi yang digunakan untuk memperbaiki lahan dengan bantuan tanaman. Teknologi ini merupakan teknologi yang ramah lingkungan, efektif serta biaya yang digunakan cukup murah (Ratnawati \& Fatmasari, 2018).

Teknologi fitoremediasi merupakan alternatif menarik dan efektif dalam mengurangi polusi di lingkungan akuatik (Lu, 2009 dalam Ali et al., 2020). Tanaman yang digunakan adalah tanaman yang memiliki kemampuan besar untuk mengakumulasi nutrisi terlarut, logam serta kontaminan lain (Lu, 2009 dalam Ali et al., 2020). Pengunaan tanaman dalam proses remediasi dikarenakan tanaman memiliki kemampuan tinggi untuk mengkonsumsi kontaminan kemudian diuapkan langsung ke atmosfer. Proses ini dapat menghemat biaya dalam menghilangkan pencemar dari tanah, air tanah, residu, dan lumpur (Girdhar, 2014 dalam Ali et al., 2020). Tanaman akan melakukan metabolisme terhadap kontaminan oleh beberapa senyawa yang diproduksi dalam jaringan tanaman melalui proses fitotransformasi atau fitodegradasi (Black, 1995; Chaudhry, 1998 dalam Ali et al., 2020). Mekanisme yang terjadi dalam proses fitoremediasi yaitu penyerapan polutan melalui akar lalu akumulasi polutan di jaringan tumbuhan kemudian membusuk dan mengubah polutan menjadi bahan yang tidak terlalu berbahaya (UNEP, 2019; Vidal, 2019 dalam Ali et al., 2020). 
Tanaman memang mampu digunakan sebagai agen fito remediasi, namun tidak semua tanaman dapat digunakan sebagai fitoremediator karena tidak semua tanaman dapat melakukan metabolisme, volatilisasi dan akumulasi polutan dengan menggunakan mekanisme yang sama. Youngman (1999) dalam (Hibatullah, 2019), menyatakan bahwa tanaman yang dapat melakukan proses fitoremediasi harus memiliki sifat sebagai berikut:

1) Cepat tumbuh

2) Mampu mengkonsumsi air dalam jumlah banyak dalam waktu singkat

3) Mampu meremediasi berbagai jenis polutan

4) Memiliki toleransi yang tinggi terhadap polutan

Tanaman yang dapat digunakan dalam proses fitoremediasi diantaranya adalah eceng gondok (Eichhornia crassipes) dan kiambang (Pistia stratiotes). Eceng gondok merupakan tumbuhan akuatik yang berasal dari Amerika yang telah menyebar ke semua negara yang memiliki iklim tropis. Eceng gondok sangat produktif dengan pertumbuhan yang tinggi sehingga mempengaruhi aliran air dan menghalangi masuknya sinar matahari serta mengurangi kadar oksigen dalam air (Priya \& Selvan, 2017). Sehingga eceng gondok memiliki dampak negatif terhadap ekosistem lahan basah yang akan mengakibatkan meningkatnya laju penguapan air yang lebih tinggi (Sukasem \& Prayoonkham, 2017). Akan tetapi eceng gondok memiliki manfaat dengan kemampuannya yang dapat menyerap zat organik, zat anorganik dan logam berat pencemar lingkungan (Herman et al., 2017).

Tumbuhan kiambang adalah tumbuhan yang memiliki kemampuan untuk tumbuh pada perairan yang memiliki kadar nutrisi rendah serta memiliki perakaran yang panjang dan lebat yang dapat menyerap polutan akan tetapi tidak menghalangi masuknya cahaya ke dalam perairan (Widiarso, 2011 dalam Rahmawati et al., 2016).

Penelitian ini bertujuan untuk mengetahui perlakuan terbaik dalam menurunkan parameter kualitas air seperti kekeruhan, warna dan bau dari limbah cair industri keripik singkong menggunakan tanaman eceng gondok, kiambang dan tawas. Pada penelitian sebelumnya yang menggunakan tiga jenis tanaman air yaitu eceng gondok, kiambang dan kangkung air untuk proses fitoremediasi limbah cair pembuatan tempe diperoleh hasil bahwa eceng gondok dan kangkung air memiliki kemampuan menurunkan kandungan parameter kualitas air yang lebih baik dibandingkan dengan tanaman kiambang (Novita et al., 2019).

Penelitian mengenai pengolahan limbah industri dengan tanaman air masih diperlukan untuk mengetahui metode pengolahan yang sederhana, mudah, ekonomis,dan ramah lingkungan. Dalam penelitian sebelumnya menggunakan tiga jenis tanaman air yaitu eceng gondok, kiambang, dan kangkung air. Sedangkan pada penelitian kali ini hanya menggunakan dua jenis tanaman air yaitu eceng gondok dan kiambang, akan tetapi menggunakan tawas sebagai perlakuan tambahan.

\section{METODE}

Penelitian ini dilakukan pada tanggal 4-14 Agustus 2020 yang bertempat di Desa Karanggondang Kecamatan Mlonggo Kabupaten Jepara. Sampel pada penelitian ini diambil dari salah satu rumah industri keripik singkong di Desa Karanggondang. Terdapat tiga macam perlakuan yang diberikan yaitu limbah cair + eceng gondok (Eg), limbah cair + kiambang (Ki) dan limbah cair + tawas (Ta). Untuk kontrol $(\mathrm{Ko})$ berupa air limbah tanpa tambahan bahan lain. Masing-masing perlakuan disusun dalam rancangan acak lengkap dengan tiga ulangan dan satu kontrol. Wadah yang digunakan yaitu berupa bak plastik berdiameter $18 \mathrm{~cm}$ dan tinggi $35 \mathrm{~cm}$ dengan volume limbah $2 \mathrm{~L} /$ bak. Parameter yang diamati yaitu bau, warna dan kekeruhan limbah. Untuk mengamati paramater warna dan kekeruhan limbah cair digunakan gelas plastik transparan agar sampel limbah cair terlihat jelas warna dan kekeruhannya setelah perlakuan.

\section{HASIL DAN PEMBAHASAN \\ Hasil}


Berdasarkan dari penelitian yang telah dilakukan selama 10 hari perlakuan menunjukkan hasil bahwa tumbuhan eceng gondok merupakan tumbuhan yang memiliki kemampuan bertahan pada air limbah paling lama. Tumbuhan eceng gondok dinyatakan mati pada hari ke 10. Sedangkan pada tumbuhan kiambang dinyatakan mati pada hari ke 6. Sebelum akhirnya dinyatakan mati, tumbuhan telah ditumbuhi jamur hingga akhirnya membusuk dan mati. Terjadi perubahan warna daun dan batang selama perlakuan dengan perubahan warna tercepat terjadi pada kiambang.
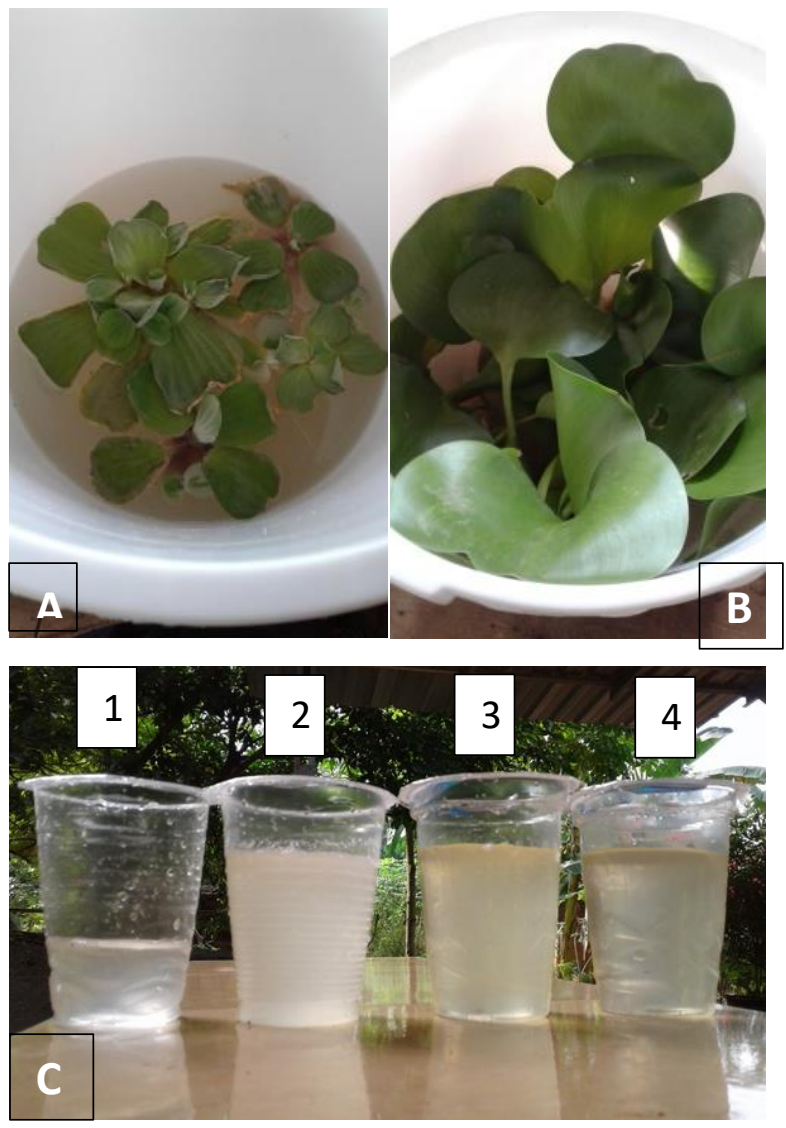

Gambar 1. Dokumentasi (A) Kiambang;

(B) Eceng Gondok; (C) Air Hasil

Pengamatan (1. Kontrol; 2. Kiambang; 3.

Eceng gondok; 4 Tawas)

TABEL 1. HASIL PENGAMATAN

\begin{tabular}{ccccc}
\hline No & $\begin{array}{c}\text { Perlaku } \\
\text { an }\end{array}$ & Bau & Warna & $\begin{array}{c}\text { Keke } \\
\text { ruha } \\
\text { n }\end{array}$ \\
\hline 1. & $\begin{array}{l}\text { Kontrol } \\
{[\text { Ko] }}\end{array}$ & Menyengat & $\begin{array}{l}\text { Tidak } \\
\text { berwarna }\end{array}$ & Jernih \\
\hline 2. & Kiamban & Menyengat & Kecoklatan & Jernih
\end{tabular}

\begin{tabular}{lllll}
\hline & $\mathrm{g}[\mathrm{Ki}]$ & & & \\
\hline 3. & $\begin{array}{l}\text { Eceng } \\
\text { gondok }\end{array}$ & Menyengat & Kecoklatan & Jernih \\
& {$[\mathrm{Eg}]$} & & & \\
\hline 4. & Tawas & Menyengat & Tidak & Jernih \\
& {$[\mathrm{Ta}]$} & & berwarna & \\
\hline
\end{tabular}

\section{Pembahasan}

Pada perlakuan tawas terbentuk endapan karena tawas yang dicampur dengan air limbah berfungsi sebagai koagulan (Haderiah, 2015). Berdasarkan penelitian sebelumnya, tawas berguna sebagai koagulan yang dapat memisahkan padatan terlarut atau suspended soloid yang secara alami memiliki laju pengendapan yang lambat (Haderiah, 2015).

Tawas atau alummunium sulfat $\left(\mathrm{Al}_{2}\left(\mathrm{SO}_{4}\right)_{3}\right.$ adalah kristal berwarna putih yang memiliki sifat dapat menarik partikel-partikel sehingga mudah mengendap (Burgess, 2015 dalam Husaini et al., 2018).

Tawas dapat digunakan sebagai bahan untuk menjernihkan air melalui proses penggumpalan padatan-padatan yang terlarut dalam limbah cair sehingga tawas dapat digunakan sebagai pembersih air (Zoubulis dan Tzoupanos, 2010 dalam Husaini et al., 2018). Tawas memiliki kemampuan untuk menjernihkan air dengan mengkoagulasi zat-zat tersuspensi sehingga menghasilkan gumpalan yang lebih besar hingga dapat terjadi proses pengendapan yang lebih cepat (Margaretha, 2012 dalam Husaini et al., 2018). Pada perlakuan kontrol juga terdapat endapan pati yang dihasilkan dari limbah cair. Endapan tersebut merupakan padatan tersuspensi zat organik tau sisa pati yang masih terkandung dalam limbah cair yang dapat menyebabkan pencemaran.

\section{Karakteristik Limbah Cair pengolahan Singkong Warna dan Bau}

Limbah cair yang berasal dari proses pencucian berwarna kecoklatan disertai suspensi dari kotoran dan kulit ubi kayu. Sedangkan pemisahan pati memiliki warna putih kekuningan. Limbah cair dari pengolahan singkong memiliki bau khas ubi kayu yang akan mudah berubah semakin menyengat apabila dibiarkan pada tempat tergenang karena adanya proses pembusukan (Prayitno, 2008).

\section{Padatan Tersuspensi}

Padatan tersuspensi merupakan pati yang terendapkan. Banyaknya padatan tersuspensi berkaitan dengan tingginya nilai BOD (Biochemical Oxygen Demand) dan COD (Chemical Oxygen Demand) pada Limbah (Prayitno, 2008). 


\section{Kandungan Limbah Cair Pengolahan Singkong \\ Limbah cair yang dihasilkan dari industri} pengolahan singkong mengandung senyawasenyawa organik tersuspensi seperti karbohidrat, protein, lemak yang mudah membusuk dan dapat menimbulkan adanya bau tak sedap. Selain mengandung senyawa organik juga mengandung senyawa anorganik berbahaya seperti $\mathrm{CN}$, nitrit, ammonia, dan lain sebagainya. Kandungan senyawa-senyawa ini dapat menyebabkan terjadinya pencemaran dan juga membahayakan kesehatan (Riyanti \& Lukitowati, 2010).

\section{Karakteristik Tanaman Fitoremediasi}

Penentuan karakteristik pada tanaman fitoremediasi selama perlakuan dengan dilihat dari warna daun pada kedua tanaman. Perubahan warna daun terjadi dalam jangka waktu 10 hari perlakuan. Perubahan yang tercepat dialami oleh tanaman kiambang yang dinyatakan mati pada hari ke 6 karena semua daun telah berubah menjadi kehitaman dan membusuk serta timbul jamur. Sedangkan pada tanaman eceng gondok dapat bertahan hingga hari ke 8 dan dinyatakan mati pada hari ke 10. Berdasarkan penelitian sebelumnya, tanaman kiambang dan eceng gondok dinyatakan mati karena semua daun telah berubah warna menjadi kecokelatan dan kering. Kematian tanaman ini dengan dugaan karena tidak terpenuhinya syarat tumbuh masing-masing tanaman sehingga tanaman tidak mampu hidup dan bertahan lebih lama (Novita et al., 2019).

\section{Parameter Kualitas Air \\ Bau}

Penentuan kualitas air secara tidak langsung dapat ditentukan dengan adanya bau yang muncul (Sari \& Huljana, 2019). Air yang memiliki bau busuk atau menyengat memiliki kandungan bahan organik yang diuraikan oleh mikroorganisme dalam air (Effendi, 2003). Berdasarkan hasil pengujian bau limbah cair dengan menggunakan indera penciuman memiliki hasil berupa adanya bau yang menyengat pada semua perlakuan. Sumber utama timbulnya bau pada limbah cair adalah adanya kandungan hidrogen sulfida dan senyawa organik dari proses dekomposisi anaerob. Bau yang muncul dapat menjadi salah satu indikator adanya gas beracun atau kondisi anaerob yang dapat merugikan untuk kesehatan dan lingkungan (Vanatta, 2000 dalam Mukarromah et al., 2016).

\section{Kekeruhan}

Menurut Effendi (2003), penyebab kekeruhan karena adanya bahan organik dan anorganik yang tersuspensi dan terlarut maupun adanya bahan organik dan anorganik berupa plankton dan mikroorganisme lain. Berdasarkan hasil pengujian kekeruhan limbah cair dengan menggunakan indera penglihatan menunjukkan adanya penurunan kekeruhan air dengan dilihat dari bahan organik maupun anorganik terlarut. Pada semua perlakuan mengalami penurunan kekeruhan, akan tetapi pada perlakuan kontrol terbentuk endapan yang merupakan bahan organanik yang tidak tereduksi dan terakumulasi. Tanaman eceng gondok memiliki kemampuan penurunan kekeruhan paling tinggi yang didukung oleh mikroba rhizosfer pada akar serta daya adsorpsi dan akumulasi akar yang besar terhadap bahan pencemar. Mikroba rhizosfer pada akar tanaman akan mereduksi bahan organik dan anorganik di dalam limbah cair. Bahan pencemar akan diserap oleh akar tanaman kemudian diakumulasikan ke bagian tanaman yang lain (Rukmi, 2013 dalam Novita et al., 2019).

\section{Warna}

Warna pada dapat menjadi indikator adanya zat terlarut dalam air yang mempengaruhi kualitas air. Warna air dapat muncul karena adanya bahan organik maupun anorganik. Warna pada air dapat diamati secara langsung dengan indera penglihatan maupun dengan melakukan pengukuran menggunakan alat pembanding skala platinum kobalt yang membandingkan warna air sampel dengan warna standar (Effendi, 2003).

Berdasarkan pengamatan diperoleh hasil bahwa pada perlakuan $\mathrm{Eg}$ dan $\mathrm{Ki}$ memiliki warna air limbah yang kecoklatan. Sedangkan pada perlakuan Ta dan Ko berwarna putih bening. Warna kecoklatan pada perlakuan $\mathrm{Eg}$ dan $\mathrm{Ki}$ timbul karena adanya dekomposisi dari tumbuhan eceng gondok dan kiambang yang telah mati. Effendi (2003) menyatakan bahwa bahan-bahan organik yang berasal dari adanya proses dekomposisi atau pelapukan tumbuhan yang telah mati akan menyebabkan air berwarna kecoklatan.

\section{KESIMPULAN}

Simpulan yang diperoleh dari penelitian ini adalah penggunaan tumbuhan eceng gondok menghasilkan sisa air yangpaling baik diantara perlakuan lain ntuk mengolah limbah dari industri keripik singkong. Karena tumbuhan eceng gondok memiliki kemampuan yang lebih lama untuk bertahan dibandingkan tumbuhan kiambang dalam proses fitoremediasi limbah cair industri keripik singkong. 
Saran yang dapat diberikan untuk masyarakat yang memiliki usaha industri baik skala besar, menengah, maupun kecil agar membuat unit instalasi pembuangan limbah cair untuk pengolahan sebelum membuang limbah cair ke lingkungan.

\section{DAFTAR PUSTAKA}

Ali, A., Naeem, M., Singh, S., \& Alzuaibr, F. M. (2020). Phytoremediation of contaminated waters: An eco-friendly technology based on aquatic macrophytes application. The Egyptian Journal of Aquatic Research, $x \times x x$. https://doi.org/10.1016/j.ejar.2020.03.00 2

Felani, M., \& Hamzah, A. (2007). Fitoremediasi limbah cair industri tapioka dengan tanaman enceng gondok. Buana Sains, 7(1), 11-20.

Herman, Y., Djo, W., Suastuti, D. A., Suprihatin, I. E., \& Dwijani, W. (2017). Fitoremediasi Menggunakan Tanaman Eceng Gondok (Eichhornia Crassipes) Untuk Menurunkan Cod Dan Kandungan $\mathrm{Cu}$ Dan Cr Limbah Cair Laboratorium Analitik Universitas Udayana. Jurnal Cakra Kimia, 5(2), 137 144.

Hibatullah, H. F. (2019). Fitoremediasi Limbah Domestik (Grey Water) Menggunakan Tanaman Kiambang (Salvinia molesta) dengan Sistem Batch.

Husaini, Cahyono, S. S., Suganal, \& Hidayat, K. N. (2018). Perbandingan Koagulan Hasil Percobaan dengan Koagulan Komersial Menggunakan Metode Jar Test. Jurnal Teknologi Mineral Dan Batubara, 14(1), 31-45.

Mukarromah, R., Yulianti, I., \& Sunarno. (2016). Analisis Sifat Fisis Kualitas Air di Mata Air Sumber Asem Dusun Kalijeruk, Desa Siwuran, Kecamatan Garung, Kabupaten Wonosobo. Unnes Physics Journal, 5(1), 40-45.

Novita, E., Arunggi, A., Hermawan, G., \& Wahyuningsih, S. (2019). Komparasi
Proses Fitoremediasi Limbah Cair Pembuatan Tempe Jurnal Agroteknologi Vol. 13 No. 01 (2019), 16-24.

Prayitno, H. T. (2008). Pemisahan padatan tersuspensi limbah cair tapioka dengan teknologi membran sebagai upaya pemanfaatan dan pengendalian pencemaran lingkungan.

Priya, E. S., \& Selvan, P. S. (2017). Water hyacinth (Eichbornia crassipes) - An efficient and economic adsorbent for textile effluent treatment - A review. Arabian Journal of Chemistry, 10, S3548S3558.

https://doi.org/10.1016/j.arabjc.2014.03. 002

Rahmawati, A., Zaman, B., \& Purwono. (2016). Kemampuan Tanaman Kiambang (Salvinia molesta) dalam Menyisihkan BOD dan Fosfat pada Limbah Domestik (Grey Water) dengan Sistem Fitoremediasi secara Kontinyu. Jurnal Teknik Lingkungan, 5(4), 1-10.

Ratnawati, R., \& Fatmasari, R. D. (2018). Fitoremediasi Tanah Tercemar Logam Timbal ( $\mathrm{Pb}$ ) Menggunakan Tanaman Lidah Mertua ( Sansevieria trifasciata) dan Jengger Ayam (Celosia plumosa). Al-Ard: Jurnal Teknik Lingkungan, 3(2), 62-69.

Riyanti, F., \& Lukitowati, P. (2010). Proses Klorinasi untuk Menurunkan Kandungan Sianida dan Nilai KOK pada Limbah Cair Tepung Tapioka. Jurnal Penelitian Sains, 13(3), 34-39.

Sari, M., \& Huljana, M. (2019). Analisis Bau, Warna, TDS, pH, dan Salinitas Air Sumur Gali di Tempat Pembuangan Akhir. ALKIMIA: Jurnal Imu Kimia Dan Terapan, 3(1), 1-5.

Sukasem, N., \& Prayoonkham, S. (2017). ScienceDirect Biomethane Recovery Fresh and Dry Water International from Anaerobic Co-Digestion with Pig Dung, Elephant Dung Assessing the feasibility of using Alkali the heat and Bat Dung with Different Pretreatments temperature function for a long-term district heat 
demand forecast. Energy Procedia, 138, 294-300. 